\title{
Effects of Acidity on Growth and Symbiotic Performance of Rhizobium leguminosarum bv. viciae Strains Isolated from Faba Bean Producing Areas of Ethiopia
}

\author{
${\text { Mulissa } \mathrm{Jida}^{1^{\star}} \text { and Fasil Assefa }}^{2}$ \\ ${ }^{1}$ Department of Biology, College of Natural and Computational Sciences, Wollega University, \\ Post Box No: 395, Nekemte, Ethiopia \\ ${ }^{2}$ Department of Microbial, Cellular and Molecular Biology, College of Natural Sciences, \\ Addis Ababa University, Addis Ababa, Ethiopia
}

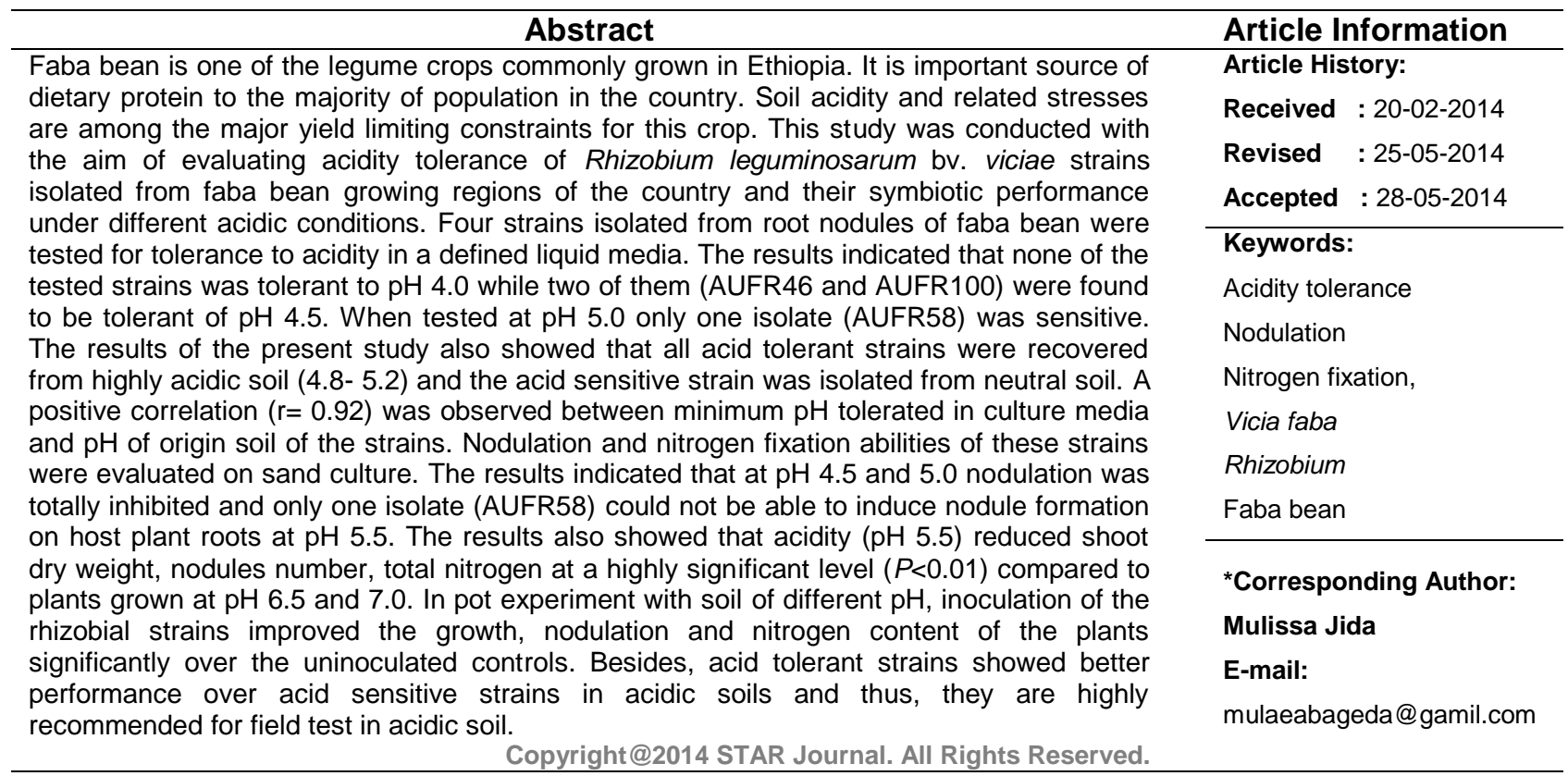

\section{INTRODUCTION}

Faba bean is one of the major pulse crops commonly grown in Ethiopia, and it ranks first in area and production. It occupies areas of $459,183.5$ ha land with annual production of $697,798.3$ tons (CSA, 2011).This grain legume is important source of dietary protein and daily food supplements to the majority of Ethiopian population. The seeds are mostly boiled and used as snack in the daily food of the rural people. They are also used in the preparation of local dishes such as 'shiro wot 'and 'kik wot' to be consumed with cereal injera. Moreover, they provide large cash for farmers and foreign exchange for the country (Desta Beyene, 1988).

In low-input agriculture systems of Ethiopia, chemical fertilizers are rarely used in the production of faba bean and other pulse crops; instead, these crops are used as a restorer of soil fertility for the following cereal crops (Asfaw Telaye et al., 1994; Mulissa Jida and Fassil
Assefa, 2012). Thus, rotation of faba bean and other pulses with cereal has been used to improve both soil fertility and structure. Therefore, the potential of this food legume as a supplier of biologically fixed nitrogen for nonleguminous crops might be more important than their potential as food or cash. In addition, this food legume and othersare predominantly cultivated in marginal agricultural areas where the other cereal crops fail to grow (Asfaw Telaye et al., 1994). Despite its multifaceted benefits the productivity of faba bean has remained very low compared to the potential. Soil related stresses such as acidity and associated low phosphate availability are among the major yield limiting constraints (Asfaw Telaye, 1985; Asfaw Telaye et al., 1994).

Soil acidity is among the common problems that limits the production of faba bean in Ethiopia (Asfaw Telaye, 1985; Asfaw Tilalye et al., 1994; Aynaebeba Adamu et al., 


\section{Mulissa Jida and Fasil Assefa}

2001; Asefa Keneni et al., 2010). Acid soil infertility is caused by toxicities of hydrogen ion, aluminum, and manganese, and deficiency of calcium, molybdenum and phosphorus (Graham, 1992; Chen et al., 1993). Soil acidity can adversely affects survival, growth and nitrogen-fixation efficiency of the rhizobia, formation of symbiotic association between rhizobia and their host legumes, (Chen et al., 1991, Chen et al., 1993, Graham, 1992; Zahran, 1999).

Generally, Rhizobium strains vary markedly in their acid tolerance and ability to nodulate their host legume on acid soil (Zahran, 1999). Several studies indicated that some rhizobia strains are acid tolerant when grown in acidic laboratory medium (Chen et al., 1993; Del Papa et al., 1999; Asefa Keneni et al., 2010; Mulissa Jida and Fassil Assefa, 2011). Though there is no basis to support that a higher acid and/or soil acid tolerance of bacteria corresponds to a better symbiotic performance under acidic conditions, Howieson et al. (1988) found that acid tolerant Sinorhizobium meliloti strains enhanced the establishment of medic pastures in mildly acidic soils. Del Papaet al. (1999) have obtained acid tolerant strains of rhizobia, which formed nodules with low rate of nitrogenfixation. Although acid tolerance and symbiotic effectiveness are both desirable bacterial traits, they are not necessarily linked (Howieson et al., 1988). Hence, selection of acid tolerant together with effective rhizobial strains is important to improve the production of legumes on acid soils.
Sci. Technol. Arts Res. J., April-June 2014, 3(2): 26-33

Several studies showed that Ethiopian soils harbored symbiotically effective rhizobia which are tolerant to different stresses such as acidity (Zerihun Belay and Fassil Assefa, 2011; Anteneh Argaw, 2012). In order to overcome low production of faba bean on acidic soils, different methods can be employed ranging from liming of soils (Marschner,1995; Achalu Chimdi et al., 2013) to that of selecting tolerant host, tolerant and effective rhizobia to achieve effective symbiosis (Carter et al.,1994; Mulissa Jida and Fassil Assefa, 2011). However, little research attentions have been given to acid tolerant rhizobia and evaluation of their symbiotic performance under acidic conditions. Hence, this study was conducted to evaluate acidity tolerance of selected Rhizobium leguminosarum bv viciae strains isolated from different faba bean growing regions of Ethiopia with different soil $\mathrm{pH}$, and their symbiotic performance under different acidic conditions.

\section{MATERIALS AND METHODS}

\section{Test Bacterial Strains}

Rhizobium leguminosarum bv. viciae strains used in this study were AUFR7, AUFR46, AUFR58 and AUFR100 (Table 1). They were selected out of 100 Rhizobium leguminosarum bv. viciae culture collection, Applied Microbiology Laboratory, Addis Ababa University (AAU), which were previously isolated from different faba bean growing areas of Ethiopia. Selection was based on their effectiveness and $\mathrm{pH}$ of the origin soil of the strains. The strains were maintained on Yeast Extract Mannitol Agar) (YEMA) slant at $4^{0} \mathrm{C}$ (Vincent, 1970). Their purity was checked regularly by streaking on YEMA plates.

Table 1: Test rhizobial strains and their isolation site geographical location.

\begin{tabular}{llllc}
\hline \multicolumn{1}{c}{ Isolate } & Isolation site & Regional state & Zone & pH of soil \\
\hline AUFR7 & Alelitu chole & Oromiya & Northern Shewa & 6.2 \\
AUFR46 & Debera Zebit & Amhara & Southern Gonder & 5.5 \\
AUFR58 & Ashengie & Tigray & Southern Tigray & 7.0 \\
AUFR100 & Holeta & Oromiya & Western Shewa & 4.8 \\
\hline
\end{tabular}

\section{Determination of Acid Tolerance of the Rhizobial Strains}

Buffered defined growth medium described by Wood et al., (1988) was used to determine the acidity tolerance levels of the rhizobial isolates. The $\mathrm{pH}$ of the medium was adjusted to $4.0,4.5,5.0,5.5,6.0$, and 6.5 with $1 \mathrm{~N} \mathrm{HCl}$ and $\mathrm{NaOH}$ using $\mathrm{pH}$ meter before autoclaving. Hundred $\mathrm{ml}$ of the medium was dispensed in 250 flasks and autoclaved. The flasks were inoculated with $1 \mathrm{ml}$ exponential phase rhizobial culture grown in YEM broth at $28^{\circ} \mathrm{C}$ for 3 days and adjusted to give an initial inoculum density of $10^{3}$ cells $\mathrm{ml}^{-1}$. The strains were grown for $120 \mathrm{hrs}$ on a rotary shaker (120rpm). Bacterial growth was followed by measuring optical density (using spectrometer at $540 \mathrm{~nm}$ ) and spreading $0.1 \mathrm{ml}$ of the culture on YEMA plate severy $12 \mathrm{hrs}$, and counting colony forming unit (CFU). Late log phase cell density $\mathrm{ml}^{-1}$ was calculated from the growth curve and used for comparisons.

\section{Symbiotic Effectiveness Test on Sand Culture under Different $\mathbf{p H}$}

Symbiotic effectiveness of the strains was evaluated on sand culture under different acidic $\mathrm{pH}$. About $3 \mathrm{~kg}$ of carefully acid washed and sterilized sand was added into plastic pots (3.5Kg capacity).The faba bean cultivar called 'Mesay' obtained from Ethiopian Institute Agricultural Research (EIAR) was used in this study. Faba bean seeds were surface sterilized with 95\% ethanol and 3\% sodium hypochlorite solutions for $10 \mathrm{~s}$ and $3 \mathrm{~min}$., respectively (Vincent, 1970) and rinsed five times with sterilized distilled water to remove traces of sterilizing chemicals. Surface sterilized seeds were allowed to germinate on a Water Agar $(0.75 \%)$ for three days at $25^{\circ} \mathrm{C}$. The rhizobial strains were cultured in YEM broth for three days. Germinated seedlings on the agar surface were flooded with rhizobial culture adjusted to $10^{9}$ cells per seed for one hour. Five inoculated seedlings were transferred on each pot which was later on thinned down to three after 10 days of planting

The pots were irrigated with nitrogen free plant nutrient solution as described by (Somasegren and Hoben, 1994). The $\mathrm{pH}$ of the solution was adjusted to $4.5,5.0,5.5,6.0$., 6.5 and 7.0 with $1 \mathrm{~N} \mathrm{HCl}$ and $\mathrm{NaOH}$ prior to autoclaving and checked after autoclaving and did not vary significantly. Each isolate was used as inoculants at each $\mathrm{pH}$ treatments. Uninoculated nitrogen-fertilized $(0.05 \%$ $\mathrm{KNO}_{3}$ solution) pots were included as control. The experiments were set in triplicate. All pots were arranged in a completely randomized block design in a glasshouse found at College of Natural Sciences, AAU. The pots were watered with sterilized distilled water adjusted to their respective $\mathrm{pH}$ once a week and the $\mathrm{pH}$ of the sand culture was monitored regularly. 


\section{Mulissa Jida and Fasil Assefa}

Sixty days after planting seedlings were carefully uprooted, and nodule number was recorded. Shoot dry weight was determined after drying at $70^{\circ} \mathrm{C}$ for $48 \mathrm{hrs}$ to the constant weight. Relative symbiotic effectiveness of each isolate was calculated by using the formula $(100 \times$ inoculated plant shoot dry weight/ $\mathrm{N}$-fertilized plant shoot dry weight) of Gibson (1987). Total nitrogen of shoot was determined by modified wet Kjeldhal method as described in Sahlemedhin Sertsu and Taye Bekele (2000).
Sci. Technol. Arts Res. J., April-June 2014, 3(2): 26-33

\section{Soil Sample Collection}

Composite soil samples of $0-30 \mathrm{~cm}$ depth were collected from Gonder (Debrezebit), Shewa (Alelitu Chole and Holeta), and Tigray (Ashenge). Each soil sample was thoroughly mixed and air-dried in a glasshouse. Air-dried soil samples were ground and passed through a $2 \mathrm{~mm}$ sieve to remove stones and large pieces of organic matter. The physicochemical characteristics of the soil samples were analyzed at Ethiopian National Soil Testing Center, Addis Ababa (Table 2).

Table 2: Soil physical and chemical properties.

\begin{tabular}{lcccc}
\hline Parameters & Alelitu & Gonder & Holeta & Tigray \\
\hline $\mathrm{pH} \mathrm{H} \mathrm{H}_{2} \mathrm{O} 1: 2.5$ & 6.3 & 5.2 & 4.8 & 6.9 \\
$\mathrm{EC}(\mathrm{dsm})$ & 0.187 & 0.125 & 0.088 & 0.980 \\
$\mathrm{Class}$ & Clay & Clay loam & Clay & Loam \\
$\mathrm{Na} \mathrm{meq} / 100 \mathrm{gm}$ & 1.140 & 0.4 & 0.540 & 0.460 \\
$\mathrm{~K}$ meq/100 gm & 2.52 & 1.62 & 1.79 & 1.32 \\
$\mathrm{Ca}$ meq/100 gm & 31.87 & 33.98 & 10.08 & 22.61 \\
$\mathrm{Mg}$ & 10.37 & 13.17 & 4.12 & 11.36 \\
$\mathrm{~T} . \mathrm{E}$.bases & 45.90 & 49.17 & 16.53 & 35.75 \\
$\mathrm{CEC}$ meq/100 & 46.67 & 50.40 & 22.00 & 36.40 \\
$\mathrm{~T} . \mathrm{N} \%$ & 0.09 & 0.118 & 0.088 & 0.112 \\
$\mathrm{O} . \mathrm{C} \%$ & 0.998 & 1.317 & 0.738 & 1.197 \\
$\mathrm{C} / \mathrm{N} \mathrm{ratio}$ & 11 & 11 & 8 & 11 \\
$\mathrm{Av} . \mathrm{P}(\mathrm{ppm})$ & 4.54 & 19.18 & 1.92 & 10.64 \\
$\mathrm{Fe}(\mathrm{ppm})$ & 26.64 & 23.92 & 9.44 & 18.92 \\
$\mathrm{Mn}(\mathrm{ppm})$ & 33.3 & 26.80 & 80.1 & 18.84 \\
$\mathrm{Zn}(\mathrm{ppm})$ & 2.30 & 2.10 & 1.50 & 1.50 \\
$\mathrm{Cu}(\mathrm{ppm})$ & 1.68 & 0.88 & 0.88 & 1.08 \\
\hline
\end{tabular}

E.C: Electrical conductivity, CEC: Cation exchange capacity, T.N.: Total nitrogen, O.C: Organic carbon, $\mathrm{C} / \mathrm{N}$ : Carbon to nitrogen ratio, Av.P: Available phosphorus, T.E: Total exchangeable bases.

\section{Symbiotic Effectiveness Test in Different soils}

The pot experiments were carried out in a glasshouse under 12 hrs (light and dark period). In order to determine the effectiveness of the strains at different soil conditions, pot experiments were carried out in a glasshouse. Three $\mathrm{kg}$ of air-dried and sieved soil was placed in plastic pots. Faba bean seeds sterilization, germination, inoculation and sowing were done as described before. Uninoculated pots were included as controls. The experiments were set in triplicates as described before. All pots were watered with distilled water twice a week. Sixty days after planting seedlings were carefully uprooted, and nodule number was recorded. Shoot dry weight and total nitrogen were analyzed as described before.

\section{Data Analysis}

All tests were set in triplicates and the data is average these. Shoot dry weight, total nitrogen, nodule number, and cell density mean separation were analyzed by
Tukey's HSD test. Pearson correlation coefficient was calculated to check the relation between minimum $\mathrm{pH}$ tolerated in minimal salt medium and the strains origin soil $\mathrm{pH}$ using (SPSS.V.15.).

\section{RESULTS}

Four selected strains of $R$. leguminosarum bv. viciae strains were tested for growth at different acidic $\mathrm{pH}$ in a buffered defined liquid medium. The results showed that none of the tested strains grew at $\mathrm{pH} 4.0$ where as all of them grew very well at $\mathrm{pH} \geq 5.5$ (Table 3 ). Two strains (AUFR46 and AUFR100) were found to be to lerant to $\mathrm{pH}$ 4.5 while AUFR7 and AUFR58 were sensitive to this $\mathrm{pH}$. Of the tested strains only AUFR58 was sensitive to $\mathrm{pH}$ 5.0. Although all tested strains grew at $\mathrm{pH} \geq 5.5$, a considerable variation was observed with respect to cell number (Table 3).

Table 3: Growth pattern of rhizobial strains at different acidic $\mathrm{pH}$.

\begin{tabular}{ccccc}
\hline pH & $\begin{array}{c}\text { AUFR7 } \\
\log _{10} \text { CFU ml }^{-1}\end{array}$ & $\begin{array}{c}\text { AUFR46 } \\
\log _{10} \text { CFU ml }^{-1}\end{array}$ & $\begin{array}{c}\text { AUFR58 } \\
\log _{10} \text { CFU ml }^{-1}\end{array}$ & $\begin{array}{c}\text { AUFR100 } \\
\log _{10} \text { CFU ml }^{-1}\end{array}$ \\
\hline 4.5 & $\mathrm{NG}$ & $7.62 \pm 0.03 \mathrm{c}$ & $\mathrm{NG}$ & $8.41 \pm 0.10 \mathrm{~b}$ \\
5.0 & $8.77 \pm 0.02 \mathrm{~b}$ & $7.88 \pm 0.1 \mathrm{c}$ & $\mathrm{NG}$ & $8.42 \pm 0.20 \mathrm{~b}$ \\
5.5 & $8.91 \pm 0.01 \mathrm{a}$ & $8.41 \pm 0.12 \mathrm{~b}$ & $8.98 \pm 0.02 \mathrm{a}$ & $8.45 \pm 0.02 \mathrm{~b}$ \\
6.0 & $8.95 \pm 0.02 \mathrm{a}$ & $8.87 \pm 0.03 \mathrm{a}$ & $9.00 \pm 0.03 \mathrm{a}$ & $8.95 \pm 0.03 \mathrm{a}$ \\
6.5 & $8.97 \pm 0.15 \mathrm{a}$ & $8.89 \pm 0.10 \mathrm{a}$ & $9.00 \pm 0.40 \mathrm{a}$ & $8.99 \pm 0.10 \mathrm{a}$ \\
\hline
\end{tabular}

Numbers in the same column and row followed by the same letter do not differ significantly at $p=0.05$ by Tukey's HSD test, NG: no growth 


\section{Mulissa Jida and Fasil Assefa}

Cell number of strain AUFR7was decreased with increased acidity level (Table 3 ). However, only some of the differences were statistically significant $(P<0.05)$. The number of cells obtained at pH 5.0 was significantly lower than that of $\mathrm{pH} 6.0$ and 6.5 (Table 3). Strain AUFR46 was found to grow slowly compared with other strains. The cell number of strain AUFR46 was affected at a highly significant level $(P<0.01)$ by acidity at $\mathrm{pH} \leq 5.5$. However, the cell number obtained at $\mathrm{pH} 6.0$ and 4.5 did not vary significantly from that obtained at $\mathrm{pH} 6.5$ and 5.0, respectively (Table 3). Cell number of strain AUFR58 reduced at $\mathrm{pH} 5.5$ and 6.0 compared with $\mathrm{pH} 6.5$ (Table 3). However, the differences were not statistically
Sci. Technol. Arts Res. J., April-June 2014, 3(2): 26-33

significant $(P>0.05)$. Cell number displayed by strain AUFR100 at $\mathrm{pH} \leq 5.5$ was found to be lower than that of $\mathrm{pH} 6.5$ and 6.0 at a highly significant level $(P<0.01)$.

The effect of acidity on symbiotic performance of the four rhizobial strains was investigated by growing the host plant at $\mathrm{pH} 4.5,5.0,5.5,6.0,6.5$ and 7.0 in sand culture. The mean shoot dry matter accumulation of inoculated faba beans was found tovary significantly with $\mathrm{pH}$ (Table 4). All isolates failed to nodulate their host plant at $\mathrm{pH} 4.5$ and 5.0 while only AUFR58 failed to form nodules on host plant at pH5.5 (Table 4).

Table 4: Shoot dry weight and total nitrogen as influenced by inoculation of rhizobial strains.

\begin{tabular}{|c|c|c|c|c|}
\hline \multirow[b]{2}{*}{ Treatment } & \multicolumn{4}{|c|}{ Shoot Dry Weight (g plant ${ }^{-1}$ ) } \\
\hline & pH 5.5 & pH 6.0 & pH 6.5 & pH 7.0 \\
\hline KNO3 & $1.04 \pm 0.04^{\mathrm{a}}$ & $1.24 \pm 0.04^{\mathrm{a}}$ & $1.35 \pm 0.04^{\mathrm{a}}$ & $1.45 \pm 0.05^{\mathrm{a}}$ \\
\hline AUFR7 & $0.84 \pm 0.5^{\mathrm{a}}$ & $0.96 \pm 0.04^{\mathrm{a}}$ & $1.4 \pm 0.06^{\mathrm{a}}$ & $1.45 \pm 0.09^{\mathrm{a}}$ \\
\hline AUF46 & $0.88 \pm 0.02^{\mathrm{a}}$ & $0.98 \pm 0.2^{\mathrm{a}}$ & $1.3 \pm 0.06^{\mathrm{a}}$ & $1.42 \pm 0.1^{\mathrm{ab}}$ \\
\hline AUFR 58 & NG & $0.72 \pm 0.02^{c}$ & $1.3 \pm 0.04^{\mathrm{a}}$ & $1.46 \pm 0.05^{\mathrm{a}}$ \\
\hline \multirow[t]{2}{*}{ AUFR100 } & $0.73 \pm+0.03^{b}$ & $0.86 \pm 0.01^{\mathrm{b}}$ & $1.2 \pm 0.1^{b}$ & $1.25 \pm 0.07^{b}$ \\
\hline & \multicolumn{4}{|c|}{ Total Nitrogen (\%) } \\
\hline Treatment & pH 5.5 & pH 6.0 & pH 6.5 & pH 7.0 \\
\hline KNO3 & $3.2 \pm 0.012^{\mathrm{a}}$ & $3.3 \pm 0.12^{\mathrm{a}}$ & $3.4 \pm 0.5^{\mathrm{a}}$ & $3.4 \pm 0.1^{a}$ \\
\hline AUFR7 & $2.2 \pm 0.07^{b}$ & $2.3 \pm 0.08^{b}$ & $2.7 \pm 0.1^{b}$ & $2.8 \pm 0.05^{b}$ \\
\hline AUF46 & $2.3 \pm 0.1^{b}$ & $2.5 \pm 0.05^{b}$ & $2.5 \pm 0.05^{\mathrm{c}}$ & $2.6 \pm 0.1^{\mathrm{c}}$ \\
\hline AUFR 58 & $N G$ & $1.3 \pm 0.06^{d}$ & $2.4 \pm 0 .^{\mathrm{ac}}$ & $2.6 \pm 0.08^{c}$ \\
\hline \multirow[t]{2}{*}{ AUFR100 } & $1.27 \pm 0.05^{d}$ & $1.4 \pm 0.1 b$ & $2.5 \pm 0.1^{c}$ & $2.5 \pm 0.06^{c}$ \\
\hline & \multicolumn{4}{|c|}{ Number of Nodules Plant ${ }^{-1}$} \\
\hline Treatment & pH 5.5 & $\mathrm{pH} 6.0$ & $\mathrm{pH} 6.5$ & pH 7.0 \\
\hline KNO3 & NG & NG & NG & NG \\
\hline AUFR7 & $34 \pm 4 b$ & $64 \pm 6^{a}$ & $67 \pm 7^{b}$ & $34 \pm 4^{c}$ \\
\hline AUF46 & $42 \pm 4^{a}$ & $67 \pm 7^{\mathrm{a}}$ & $78 \pm 8^{a}$ & $42 \pm 4^{b}$ \\
\hline AUFR 58 & $N G$ & $10 \pm 3^{b}$ & $93 \pm 4^{a}$ & $95 \pm 3^{a}$ \\
\hline AUFR100 & $7.3 \pm 2^{c}$ & $8.0 \pm 2^{b}$ & $18 \pm 4^{\mathrm{C}}$ & $17 \pm 2^{d}$ \\
\hline
\end{tabular}

The nodulating isolates showed variation in the mean shoot dry matter accumulation in relation with the different $\mathrm{pH}$ treatments (Table 4). The highest dry matter accumulation of $0.88 \mathrm{~g} \mathrm{plant}^{-1}$ was recorded by the isolate AUFR46 followed by isolate AUFR7 with $0.84 \mathrm{~g} \mathrm{plant}^{-1}$ at $\mathrm{pH}$ 5.5; consequently they displayed very effective symbiotic effectiveness of 84.6 and $80.8 \%$, respectively, compared to the $\mathrm{N}$-fertilized positive control (Table 5). These isolates were found to be significantly different from isolate AUFR100 with only 0.73 gplant $^{-1}$ shoot dry matter yield and $70.2 \%$ effectiveness from the control plants. The isolates were found to accumulate shoot dry matter ranging from 0.72 to $0.98 \mathrm{~g} \mathrm{plant}^{-1}$ at $\mathrm{pH} 6.0$. In all cases a steady increase in shoot dry matter yield and concomitant increase in symbiotic effectiveness $(86 \%$ - 100\%)was observed as the $\mathrm{pH}$ increase.

Isolate AUFR46 induced the highest number of nodules (42 nodules plant ${ }^{-1}$ ) followed by AUFR7 with 34 nodules plant $^{-1}$ with significant difference from each other at $\mathrm{pH}$ 5.5. The least nodule number, i.e. 7.3 nodules plant ${ }^{1}$ was recorded for AUFR100 inoculated host plants. In all cases there was a significant increase in nodule number as the $\mathrm{pH}$ of growth medium increase. The total nitrogen content of the host plants also showed variations at $\geq 5.5$. In all cases $\mathrm{N}$-fertilized plants displayed the highest $\mathrm{N}$ content of shoot, $3.2 \%$ to $3.4 \%$ (Table 4 ). However, the rhizobial inoculated plants showed discrepancies in \% of $\mathrm{N}$-content at different $\mathrm{pH}$ treatments. At $\mathrm{pH} 5.5$ and 6.0, isolate AUFR7 and AUFR46 were found to accumulate N content of $2.2 \%$ and $2.3 \%$ which was about $30 \%$ less than $\mathrm{N}$-fertilized plants (Table 4).

The results of pot experiment using different soils indicated that the performance of isolate AUFR58 and AUFR100 with regard to $\mathrm{N}$-fixation and efficiency in shoot dry matter yield was similar, except that isolate AUFR100 was found to be as efficient as AUFR7 and AUFR46 on Tigray soil (Table 5). In all cases the performance of all isolates was lower on Holeta soil (Table 5). However, these isolates (AUFR7 and AUFR46) were found to be performing better than isolates AUFR58 and AUFR100 in all soil types, except Holeta soil. 
Table 5: Relative symbiotic effectiveness of the rhizobial isolates under different $\mathrm{pH}$

\begin{tabular}{lcccc}
\hline \multicolumn{5}{c}{ Relative symbiotic effectiveness (\%) } \\
\hline Treatments & pH 5.5 & pH 6.0 & pH 6.5 & pH 7.0 \\
\hline KNO3 & 100 & 100 & 100 & 100 \\
AUFR7 & 80.8 & 77.4 & 103.7 & 100 \\
AUF46 & 84.6 & 79.0 & 96.3 & 97.9 \\
AUFR 58 & NG & 58.1 & 96.3 & 100.7 \\
AUFR100 & 70.2 & 69.4 & 88.9 & 86.2 \\
\hline
\end{tabular}

Relative symbiotic effectiveness $=100 \times$ inoculated plant shoot dry weight/

$\mathrm{N}$-fertilized plant shoot dry weight(Gibson (1987), NG; no growth

The data also showed that isolate AUFR7 induced the highest shoot dry matter accumulation on all the soil types with significant and non-significant differences among the different treatments (Table 5). This isolate was found to be 1.3 to 2 times more effective in shoot dry mass compared to the uninoculated control plants. Similarly, plants inoculated with isolate AUFR46 were found to perform as well as AUFR7, except on Alelitu and Holeta soil. Although shoot dry matter accumulation of the host plant with different isolate and soil types was variable, the difference in $\mathrm{N}$ uptake and accumulation was not significantly different. The data showed that the plants with different treatments accumulated $\mathrm{N}$ content ranging from 1.73-3.38\%. In general, it appears that isolate AUFR7, AUFR46 and AUFR58 showed variation in $\mathrm{N}$ content with different soil types (Table 6).

Table 6: Shoot dry weight and total nitrogen as influenced by rhizobial inoculation

\begin{tabular}{|c|c|c|c|c|}
\hline \multirow[b]{2}{*}{ Treatment } & \multicolumn{4}{|c|}{ Shoot dry Weight $\left(\right.$ g plant $^{-1}$ ) } \\
\hline & Alelitu & Gonder & Tigray & Holeta \\
\hline AUFR7 & $1.5 \pm 0.04^{\mathrm{a}}$ & $1.2 \pm 0.05^{\mathrm{a}}$ & $1.2 \pm 0.05^{\mathrm{a}}$ & $1.0 \pm 0.06^{\mathrm{a}}$ \\
\hline AUF46 & $1.24 \pm 0.4^{b}$ & $1.16 \pm 0.06^{\mathrm{a}}$ & $1.15 \pm 0.07^{\mathrm{a}}$ & $0.8 \pm 0.07^{b}$ \\
\hline AUFR 58 & $0.94 \pm 0.03^{\mathrm{C}}$ & $0.86 \pm 0.06^{b}$ & $0.95 \pm 0.05$ & $0.76 \pm 0.03^{c}$ \\
\hline AUFR100 & $0.97 \pm 0.03^{c}$ & $0.91 \pm 0.04^{b}$ & $1.15 \pm 0.06^{\mathrm{a}}$ & $0.84 \pm 0.05^{b}$ \\
\hline \multirow[t]{2}{*}{ Unioculated } & $0.74 \pm 0.04^{d}$ & $0.78 \pm 0.07^{c}$ & $0.76 \pm 0.04^{\mathrm{C}}$ & $0.72 \pm 0.02^{\mathrm{C}}$ \\
\hline & \multicolumn{4}{|c|}{ Total Nitrogen (\%) } \\
\hline Treatment & Alelitu & Gonder & Tigray & Holeta \\
\hline AUFR7 & $2.87 \pm 0.12^{b}$ & $3.19 \pm 0.12^{\mathrm{a}}$ & $2.59 \pm 0.03^{b}$ & $2.17 \pm 0.07^{\mathrm{C}}$ \\
\hline AUF46 & $2.92 \pm 0.18^{\mathrm{a}}$ & $2.73 \pm 0.10^{b}$ & $3.19 \pm 0.13^{\mathrm{a}}$ & $2.76 \pm 0.10^{\mathrm{a}}$ \\
\hline AUFR 58 & $2.81 \pm 0.22^{b}$ & $2.40 \pm 0.10^{c}$ & $3.38 \pm 0.5^{\mathrm{a}}$ & $2.48 \pm 0.05^{b}$ \\
\hline AUFR100 & $2.52 \pm 0.10^{b}$ & $2.62 \pm .10^{\mathrm{b}}$ & $2.22 \pm 0.07^{d}$ & $1.73 \pm 0.03^{d}$ \\
\hline \multirow[t]{2}{*}{ Unioculated } & $2.25 \pm 0.12^{\mathrm{C}}$ & $2.38 \pm 0.05^{\mathrm{C}}$ & $2.46 \pm 0.1 .6^{\mathrm{c}}$ & $1.29 \pm 0.05^{\mathrm{e}}$ \\
\hline & \multicolumn{4}{|c|}{ Number of Nodules Plant ${ }^{-1}$} \\
\hline Treatment & Alelitu & Gonder & Tigray & Holeta \\
\hline AUFR7 & $159 \pm 10^{\mathrm{a}}$ & $103 \pm 8^{a}$ & $152 \pm 11^{\mathrm{a}}$ & $53 \pm 8^{b}$ \\
\hline AUF46 & $121 \pm 23^{a}$ & $65 \pm 7^{b}$ & $96 \pm 6^{\mathrm{b}}$ & $24 \pm 5^{c}$ \\
\hline AUFR 58 & $85 \pm 10^{b}$ & $36 \pm 6^{c}$ & $97 \pm 8^{b}$ & $27 \pm 8^{c}$ \\
\hline AUFR100 & $99 \pm 10^{b}$ & $63 \pm 5^{b}$ & $117 \pm 16^{\mathrm{a}}$ & $80 \pm 10^{a}$ \\
\hline Unioculated & $81 \pm 7^{b}$ & $23 \pm 3^{d}$ & $59 \pm 10^{c}$ & $23 \pm 10^{c}$ \\
\hline
\end{tabular}

\section{DISCUSSION}

The acidity tolerance study in a defined liquid medium at different acidic $\mathrm{pH}$ showed that none of the faba bean rhizobia was found to grow at $\mathrm{pH}$ 4.0. However, isolate AUFR46 and AUFR100 were found to be tolerant of $\mathrm{pH}$ 4.5. At $\mathrm{pH} 5.0$ only isolate AUFR58 was found to be sensitive. All isolates showed growth at $\mathrm{pH} \geq 5.5$. According to the classification of Del Papa et al. (1999) AUFR7, AUFR46, and AUFR100 can be grouped as acid tolerant whereas one isolate AUFR58 can be considered as mild-acid tolerant.

Lindstrom and Myllyneimi (1987) have found that the lowest $\mathrm{pH}$ at which growth was observed for Rhizobium leguminosarum was varied between 4.7 and 4.9. In contrast, the present study found that the lowest $\mathrm{pH}$ at which growth was observed for Rhizobium leguminosarum bv. viciae varied considerably. It was found to be between 4.5 and 5.5. The result of this study indicated that the lowest $\mathrm{pH}$ at which growth was observed has a positive correlation with the $\mathrm{pH}$ of isolation site. All strains which showed growth at the lowest $\mathrm{pH}$ and considered as acid tolerant were recovered from highly acidic soil ( $\mathrm{pH} 4.8$ and 5.2) and strains which grew at $\mathrm{pH}$ 5.5 was isolated from neutral soil $(\mathrm{pH} 7.0)$. Similarly Del Papa et al (1999) have reported that all acid tolerant strains of alfalfa-nodulating rhizobia were recovered from acidic soils between 5.0 and 6.5 , and most mildly acid tolerant and acid sensitive strains were obtained from soils above this $\mathrm{pH}$. Furthermore; our result demonstrated 


\section{Mulissa Jida and Fasil Assefa}

the existence of similar population of acid tolerant faba bean nodulating Rhizobium strains in geographically distant regions that have soil acidity as a common feature. The occurrence of acid tolerant strains in acid soil may relate to a better adaptation of these rhizobia to their habitat.

The ability of the isolates to induce nodulation and nitrogen-fixation was tested under different acidic conditions. The data showed that nodulation was totally inhibited at 4.5 and 5.0. All isolates induced nodulation at $\mathrm{pH} 5.5$, except AUFR58. The superior acidity tolerance of isolate AUFR46 and AUFR100 was not associated with their nodulation ability at the same $\mathrm{pH}$. Evans et al. (1980) observed that nodulation of Pisum sativum was more susceptible to acidity than either rhizobia multiplication or plant growth. Furthermore it was shown that multiplication in liquid culture is not an indicator for nodulating ability under acidic conditions; instead it improves their competitive ability under acidic conditions (Cooper et al., 1985; Wood et al. 1988).

The results of this study also demonstrated that variations amongst the acid tolerant inoculants with regard to number of nodule, shoot dry matter and total nitrogen contents of the inoculated plants. Low $\mathrm{pH}$ (5.5) reduced nodules number, shoot biomass and total nitrogen of plants inoculated with isolate AUFR7, AUFR46, AUFR100 at a highly significant level $(P<0.01)$ when compared with their corresponding plants grown at $\mathrm{pH}$ 7.0. Vassileva et al. (1997) obtained that number of nodules, nitrogenase activity, and fresh weight and dry weight of nodules were affected to a greater extent by acidity. Similarly, Paulino et al. (1987) have found that low pH (5.2) decreased nodule number and acetylene reduction in Rhizobium-Pisum sativum associations. Effect of low $\mathrm{pH}$ on plant dry weight and total nitrogen can be associated with restricted nodulation and nitrogenase activity.

In the present work symbiotic performance of the four rhizobial isolates on sand culture of different acidic $\mathrm{pH}$ was found to be different, that is the more acid tolerant strains in laboratory media performed more than the less tolerant isolate at low $\mathrm{pH}(5.5$ and 6.0). Similarly, Lindstrom et al. (1985) have observed the performance of the Rhizobium leguminosarum bv. trifolii-Trifolium pretense symbiosis were best when the Rhizobial strains were acid tolerant strains.

The pot experiments showed that the faba bean cultivar itself suffered from $\mathrm{pH}$ stress imposed at $\mathrm{pH} 4.5$ 5.0 , and 5.5 (Table 3 ). This is evidenced form reduced shoot dry matter and total nitrogen contents of plants compared with the host plants grown at $\mathrm{pH}$ 7.0. Similar result was reported for Trifolium partense (Lindstrom and Myllyeimi, 1987). Under acidic conditions growth of the legumes appears to be one of the limiting factors for legume symbiosis. Yan et al. (1992) have demonstrated that low $\mathrm{pH}$ of rooting medium limited dry matter production during vegetative plant growth, and broad bean (Vicia faba L.) was found to be particularly sensitive low pH (Schubert et al., 1990).

According to Desta Beyene and Angaw Tsige (1989) based on their nitrogen status; Gonder and Tigray soils can be classified as medium whereas Alelitu and Holeta can be classified as low (Table 2). Based on their available phosphorus Gonder soil can be classified as
Sci. Technol. Arts Res. J., April-June 2014, 3(2): 26-33

high, Tigray soil as medium, and Alelitu and Holeta soil as very low (Ngeborg, 1986). Consequently, the low number of nodules produced by plants grown on Gonder soil can be attributed to high nitrogen content and that of Holeta soil to low available phosphate and highly acidic soil pH.

The data of our pot experiment showed that inoculation of faba bean with the Rhizobial strains improved plant growth, nodulation and total nitrogen over uninoculated controls. In addition, our result indicated that in acidic soil acid tolerant isolate showed comparative advantage over acid sensitive isolate in the ability to nodulate the faba beans and to fix nitrogen. The symbiotic performance of all strains except AUFR58 was found to be less when compared the plants grown on other soils. This was may be due to high concentration of $\mathrm{Mn}$, low available phosphorus, and highly acidic $\mathrm{pH}$ and other related factors.

Lindstrom and Myllyneimi (1987) have observed that in pot experiment with acidic soil inoculation with the best strain improved the yields the plants fourteen fold compared with uninoculated controls. Hartel and Buton (1989) have observed that acid tolerant Medicago sativa L inoculated with acid tolerant rhizobia produced greater top growth, nodule number and weight, and acetylene reduction value in acid soil than the same plants inoculated with acid sensitive strains. The present findings are consistent with this result.

It is difficult to relate the tolerance of the strains to acid stress in liquid culture to its performance in acid soil, because of the difficulties in measuring the $\mathrm{pH}$ encountered by the bacteria in the rhizosphere (Wood et al., 1988). The concept of concentration of ions is complicated in soils that are characterized by exchange of reaction, and the $\mathrm{pH}$ value of soil is not well-defined measurement (White, 1969). In our pot experiment, the $\mathrm{pH}$ value of some of the soil was below the limit of multiplication for some strains. Nevertheless, all strains produced nodules on faba bean in all tested soils. This may be explained the acidity of the rhizosphere may be different from that in the soil away from the roots (Jarvis and Roson, 1983, Marschner, 1995). However, the result of this study suggests that $\mathrm{pH}$ of isolation site of the strains could be used to predict their performance in acidic soils.

\section{CONCLUSIONS}

In conclusion Rhizobium leguminosarum bv. viciae strains recovered from highly acidic soils were highly acid tolerant, isolate recovered from mildly acidic soils was found to be moderately acid tolerant, and strains which come from neutral soil was acid sensitive or less tolerant. Hence, it can be suggested that $\mathrm{pH}$ of isolation site can be used to predict acid tolerance of the rhizobial strains in liquid laboratory media.

In sand culture where the stress factor was only $\mathrm{H}^{+}$ ions the symbiotic performance of the Rhizobium leguminosarum bv. viciae strains tolerance in laboratory were found to be related with their symbiotic performance in acidic sand culture. Most acid tolerant strains where performed well at acidic $\mathrm{pH}$ and acid sensitive strains did not nodulated faba bean at $\mathrm{pH} 5.5$, but performed best at neutral $\mathrm{pH}$. For all tested Rhizobium strains-faba bean symbiosis shoot length, shoot dry weight, number of 


\section{Mulissa Jida and Fasil Assefa}

nodules and dry weight, and total nitrogen were highly reduced by decreasing $\mathrm{pH}$ from 7.0 to 5.5 .

In pot experiment, inoculation of faba beans improved growth and nitrogen content of the plants when compared with uninoculated controls. Thus, there is a potential of using rhizobial isolate to improve the yields of faba bean in acidic soils. Based on the above conclusion the following can be recommended: more screening and then selection of acid tolerant strains with superior symbiotic effectiveness which would be used as inoculant should be done from all acidic soils and faba bean producing areas of the country. Furthermore, studies on molecular basis of the acidity tolerance of Rhizobium leguminosarum bv viciae, and their interaction with faba bean at acidic soils are very important. In order to use the best strain for inoculation of faba bean on acid soils appropriate field test is highly needed.

\section{ACKNOWLEDGEMENTS}

The authors are very much grateful to Addis Ababa University, School of Graduate Studies for financial support and Ethiopian Institute Agricultural Research, Holeta for kindly providing the faba bean seeds.

\section{REFERENCES}

Achalu Chimdi., Heluf Gebrekidan., Kibebaw Kibret., Abi Tadesse. (2013). Changes in soil chemical properties as influenced by liming and its effects on barely grain yield on soils of different land use system of East Wollega, Ethiopia. World Applied Science Journal 24:1435-1441.

Anteneh Argaw. (2012). Characterization of rhizobia nodulating faba bean (Vicia faba L.) isolated from central Ethiopia. Research Journal of Microbiology 7: 280-296.

Asefa Keneni., Fassil Assefa., Prabu, P.C. (2010). Characterization of acid and salt tolerant rhizobial strains isolated from faba bean fields of Wollo, Northern Ethiopia. Journal of Agricultural Science and Technology 12: 365376.

Asfaw Telaye., Geletu Bejiga., Alem Berhe. (1994). Role of Cool season food legumes and their production constraints in Ethiopian agriculture. In: Asfaw Tilaye, Geletu Bejiga, Saxena, M.C. and Solh, M.B.(Eds), Cool seasons food legumes of Ethiopia,ICARDA (International center for Aricultural Rsearch in the Dry Areas,), Addis Ababa, Ethiopiapp3-19.

Asfaw Tilaye (1985). Faba bean in Ethiopia. FABIS News Letter 12: 3-4.

Ayanaba, A., Asanuma, S., Munns, D.N. (1983). An agar plate method for rapid screening of Rhizobium for tolerance to acid and aluminium stress. Soil Science Society of America Journal 47: 256-258.

Ayneabeba Adamu., Fassil Assefa., Endashaw Bekele. (2000). Studies of Rhizobium inoculation and fertilizer treatment on growth and production of faba bean (Vicia faba L.) in some yield-depleted and yield-sustained areas of Simen Shewa. SINET; Ethiopian Journal of Sciences 24:197-211.

Carte, J.M., Gardner, W.K., Gibson, A.H. (1994). Improved growth and yield of faba beans (Vicia faba CV. Fiord) by inoculation with strains of Rhizobium leguminosarum biovar viciae in acid soils in South West Victoria. Australian Journal of Agricultural Research 45: 613-623.

Chen, H., Cartner, E., Rolfe, B.G. (1993). Involvement of genes on a megaplasmid in the acid tolerant phenotye of
Sci. Technol. Arts Res. J., April-June 2014, 3(2): 26-33

Rhizobium leguminosarum biovar trifolii. Applied and Environmental Microbiology 59: 1058-1064.

Chen, H., Richardson, A.E., Cartner, E., Diordjevic, M.A., Roughley, R.J., Rolfe, B.G. (1991). Construction of an acid tolerant Rhizobium leguminosarum biovar trifoli strain with enhanced capacity for nitrogen fixation. Appl Applied and Environmental Microbiology 57: 2005-2011.

Cooper, J.E., Wood, M., Bjourson, A.T. (1985). Nodulation of Lotus pendncuatus in acid rooting solution by fast- and slow-growing rhizobia. Soil Biology and Biochemistry 17:487-492

CSA (Central Statistical Authority) (2011). Agricultural samples survey 2010/2011 (2003 E.C.): report on area and production of major crops. Volume I. Statistical Bulletin, Addis Ababa, Ethiopia.

Del Papa, M.F., Balaque, L.J., Sowinski, S.C., Wegner, C., Segudo, E., Abrca, F.M., Toro, N., Nichaul, K., Puhler, A., Aguilar, O.M., Martinez-Drets, G., Lagares, A. (1999). Isolation and characterization of alfalfa nodulating rhizobia present in acidic soils of central Argentina and Uruguay. Applied and Environmental Microbiology 65: 1420-1427.

Desta Beyene (1988). Biological nitrogen fixation research on grain legumes in Ethiopia. In:Beck,D.P. and Matrons, L.A. (Eds), Nitrogen fixation by legumes in Mediterranean Agriculture,Marthins Nijhoff Publishers, Dordorecht, Boston, Lancaster, pp73-78.

Desta Beyene., Angaw Tsige. (1989). Conserving mioorganisms in the soil. Soil science research in Ethiopia. Proceedings of the first soil science research review workshop. 11-14, February, 1986, Addis Ababa, Ethiopia.

Evans, L.S., Lewin, K.F., Vella, F.A. (1980): Effect of nutrient medium $\mathrm{pH}$ on symbiotic nitrogen fixation by Rhizobium leguminosarum ad Pisum sativum. Plant Soil 56: 71-80.

Gibson, A.H. (1987). Evaluation of nitrogen fixation by legumes in thegreenhouse and growth chamber. In: Gibson AH (Ed), SymbioticNitrogen Fixation Technology, New York, Marcel Dekker, pp. 321-363.

Graham, P.H. (1992). Stress tolerance in Rizobium and Bradyrhizobium, and nodulation under adverse soil conditions. Canadian Journal of Microbiology 38: 475484.

Hartel, P.G., Bouton, J.H. (1991). Rhizobium meliloti inoculation of alfalfa selected for tolerance to acid, aluminum-rich soils. Plant and Soil 116: 283-285.

Howieson, J.G., Ewing, M.A. and D'Antuono, M.F. (1988) Selection for acid tolerance in Rhizobium meliloti. Plant and Soil 105: 179-188.

Jarvis, S. C., Obson, A.D. (1983). A comparison of the cation - anion balance of ten cultivars of Trifoliu subterraneum $\mathrm{L}$. and their effect on acidity. Plant and Soil 75: 235-243.

Lindstrom, K., Myllyniemi, H. (1987).Sensitivity of red clover rhizobia to soil acidity factors in pure culture and in symbiosis. Plant and Soil 98: 353-362.

Lindstrom, K., Sorsa, M., Polkuen,J., Kansaner, P. (1985). Symbiotic nitrogen fixation of Rhizobium (Galega) in acid soils, and its survival in soil under acidic and cold stress. Plant and Soil 87: 293-302.

Marschner, $H$. (1995). Mineral nutrition of higher plants. $2^{\text {nd }} e d$. Harcourt science and Technology Company, New York, London, Sydney, Tokyo, Boston, pp. 889 


\section{Mulissa Jida and Fasil Assefa}

Mulissa Jida, Fassil Assefa (2011). Phenotypic and plant growth promoting characteristics of Rhizobium leguminosarum bv. viciae from lentil growing areas of Ethiopia. African Journal of Microbiology Research 5: 4133-4142.

Mulissa Jida, Fassil Assefa (2012). Phenotypic diversity and plant growth promoting characteristics of Mesorhizobium species isolated from chickpea (Cicer arietinum L.) growing areas of Ethiopia. African Journal of Biotechnology 11: 7483-7493.

Ngeborg, I.I. (1986). Soil survey in state farms, Problems realized and proposals for further research work to solve the problems. Proceedings of the first soil science research review workshop 11-14 February, 1986. Addis Ababa, Ethiopia.

Paulino, V.T., Olivares, J., Bedmar, E.J. (1987). Nodulation and nitrogenase activity of pea nodules as affected by low pH and aluminium. Plant and Soil 101: 299-302.

Sahlemedhin Sertsu, Taye Bekele (2000). Procedures for soi and plant analysis. Technical Paper. National Soil Research Center. Ethiopian Agricultural Research Organization, Addis Ababa, Ethiopia.

Schubert, S., Schubert, E., Mengel, K. (1990). Effects of low $\mathrm{pH}$ of the root medium on proton release, growth and nutrient uptake of field beans (Vicia faba L.). Plant and Soil 124: 239-244.

Somasegaran, P., Hoben, H.J. (1994). Handbook for Rhizobia methods inLegume-Rhizobium Technology, springer Verlag, New York, USA.
Sci. Technol. Arts Res. J., April-June 2014, 3(2): 26-33

Vassileva, V., Milanv, G., Ignatov, G., Nikolov, B. (1997). Effect of low pH on nitrogen fixation of common bean grown at various calcium and nitrate levels. Journal of Plant Nutrition 20:279-284.

Vincent, J.M. (1970). A manual for the practical study of root nodule bacteria. Blackwell Oxford, Edinburgh, UK, pp.164.

White, R.E. (1969). On the measurement of soil pH. Journal of the Australian Institute of Agricultural Science 35: 3-14

Wood, M., Copper, J.E., Bjourson, A. J. (1988). Response of Lotus rhizobia to acidity and aluminium in liquid culture and in soil. Plant and Soil 107: 227-231.

Wood, S.M., Newcomb, W. (1989). Nodule morphogenesis: The early infection of alfalfa (Medicago sativa) root hairs by Rhizobium meliloti. Canadian Journal of Botony 67: 3108-3122.

Yan, F., Schubert, S., Mengel, K. (1992). Effect of low root medium $\mathrm{pH}$ on net proton release, root respiration and root growth of con (Zea mays L) and broad bean (Vicia faba L.). Journal of Plant Nutrition 14:123-129.

Zahran, H.H. (1999). Rhizoium-legume symbiosis and nitrogen fixation under severe conditions and in arid climate. Microbiology and Molecular Biology Reviews 63: 968-989.

Zerihun Belay and Fassil Assefa (2011). Symbiotic and phenotypic diversity of Rhizobium leguminosarum bv. viciae from Northern Gondar, Ethiopia. African Journal of Biotechnology 10: 4372- 4379. 